Running head: VOLUNTEER-FAMILY CONFLICT AND TURNOVER INTENTIONS 1

1 7 Educational Sciences, Vrije Universiteit Brussel.

8 $9 \mathrm{PhD}$ and for the pleasant GOA meetings!

10 PhD and for the pleasant GOA meetings!

\author{
Volunteer-family conflict and turnover intentions: Exploring the role of psychological \\ contract features
}

Tim Vantilborgh ${ }^{1}$

1 Vrije Universiteit Brussel

Work and Organizational Psychology (WOPs) research unit, faculty of Psychology and

This chapter is dedicated to Marc Jegers. Thank you for your honest advice during my Correspondence concerning this article should be addressed to Tim Vantilborgh, Pleinlaan 2, 1050 Brussels, Belgium. E-mail: tim.vantilborgh@vub.be 
Abstract

Volunteer turnover is a key issue for non-profit organizations and various reasons for turnover have been explored in the literature. I introduce a new concept that captures conflict between the volunteering and the family domains in life and test whether it can explain turnover of volunteers. Moreover, I test whether features of volunteers' psychological contracts can explain why volunteers experience conflict between these domains in life. These features capture the key characteristics of the exchange relationship and the mutual obligations between the volunteer and the non-profit organization. As such, the goal of this study is to test a model in which volunteer-family conflict mediates the relationship between psychological contract features and volunteer turnover. The results of the study cannot confirm that volunteer-family conflict mediates this relationship. However, the findings support that volunteers who experience conflict are more likely to quit, and that the time-frame and stability features of the psychological contract can explain why volunteers experience conflict. In particular, I show that a long-term time-frame in volunteers' psychological contracts is a double-edged sword for non-profit organizations: while it directly reduces the likelihood of volunteers quitting, it also increases the risk of volunteer-family conflict. Overall, this study shows that volunteer-family conflict can be a valuable concept to understand volunteers' behaviors.

Keywords: volunteering, volunteer-family conflict, turnover, psychological contract Word count: X 


\section{Volunteer-family conflict and turnover intentions: Exploring the role of psychological contract features}

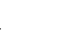

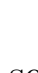
services to their beneficiaries. Non-profit organizations therefore often invest many resources to attract, train, and retain volunteers. As a result, it comes as no surprise that volunteer turnover carries considerable costs for non-profit organizations (Miller, Powell, \& Seltzer, 1990). A large body of literature has examined the reasons for volunteers to quit (Hustinx, 2010; Miller et al., 1990; Willems et al., 2012). While various organizational and personal factors have been identified, it is also clear that volunteers often quit because volunteering interferes with their personal life. For example, Hustinx (2010) describes that volunteers often mention personal reasons for quitting, such as not being able to spend enough time with their families or desiring more leisure time. In this chapter, I explore how conflict between volunteering and personal life creates tension that may lead volunteers to quit. Drawing an analogy with the literature on work-family conflict (Butler, Grzywacz, Bass, \& Linney, 2005), I introduce the concept of volunteer-family conflict, which reflects conflict between these two domains in life. I empirically test if volunteer-family conflict relates to intentions of volunteers to quit their organization. Moreover, I explore if characteristics of the exchange relationship between the volunteer and the non-profit organization can help to explain why volunteers experience conflict between both domains.

This chapter makes three main contributions to the volunteering literature. First, I add to the literature on volunteers' reasons to quit by focusing on personal reasons for leaving. Overall, such personal reasons for leaving received less attention to date compared to other reasons to quit, such as volunteer functional motives and personality (Willems et al., 2012). Second, I introduce a novel concept to better understand volunteers' personal reasons to quit, namely volunteer-family conflict. I illustrate how this concept captures potential conflicts between various domains in volunteers' lives, and empirically demonstrate that it 
can be used to explain volunteer turnover. While personal reasons to quit can be diverse for volunteers, I argue that they typically result in turnover because they engender a conflict. Third, I build on the psychological contract literature to explore why volunteers experience conflict between their volunteering activities and their private life. In particular, I focus on the features of the psychological contract (Sels, Janssens, \& Van Den Brande, 2004) to better understand the exchange relationship between volunteers and non-profit organizations, and propose that several of these features increase these risk of experiencing volunteer-family conflict. Knowing how these features relate to conflict is essential for non-profit organizations, as this allows them to adapt their management practices to avoid volunteers experiencing conflict and, thus, reduce volunteer turnover.

\section{Volunteer-family conflict}

Various domains in life are relevant for adults, and the literature often focuses on two domains that are considered salient for many, namely work and family (Butler et al., 2005). Much of this literature focuses on the conflict or incompatibility that can arise between these two domains (i.e., work-family conflict), while there has also been attention for the extent to which both domains can facilitate and enrich each other (i.e., work-family enrichment) (Butler et al., 2005). For example, paid employees may experience conflict when their job requires them to work overtime during the weekend, thus hindering family activities. Likewise, paid employees may experience enrichment as the skills that they learn at work may be helpful in a family context. Broadly speaking, work-family conflict can be considered a job demand whereas work-family enrichment can be described as a job resource (Bakker \& Demerouti, 2007). According to the job demands-resources model (Bakker \& Demerouti, 2007), experiencing job demands triggers a health impairment process that leads to exhaustion and negative outcomes such as burnout and ill-being (Lesener, Gusy, \& Wolter, 2018). Job resources, on the other hand, help to keep people engaged and motivated, and 
has been shown to lead to positive outcomes such as higher commitment and performance (Bakker, Demerouti, \& Verbeke, 2004; Hakanen, Schaufeli, \& Ahola, 2008). Moreover, job resources help buffer against the negative effects of high job demands (Bakker \& Demerouti, 2007). While there is a large body of literature on the interface between the work and family domains, other domains in life are obviously also relevant to many people. In particular, the interface between the volunteer and the family domain appears highly relevant for people who devote time to volunteer for nonprofit organizations. With volunteering, we refer to performing activities that benefit others, in a formal organization without receiving a remuneration (Vantilborgh, 2015).

Akin to work-family conflict and enrichment, I argue that people can experience incompatibility and conflict or enrichment between the volunteer and the family domains. For example, volunteers may experience conflict as the hours they devote to volunteering may reduce the time they have available for family activities and they may experience enrichment as the social relationships that they develop while volunteering may enrich the social activities in their family life. In this chapter, I will focus specifically on volunteer-family conflict. It is important to point out that conflict can emerge from the volunteer domain interfering with the family domain (i.e., volunteer-family conflict) and from the family domain interfering with the volunteer domain (i.e., family-volunteer conflict).

\section{Effects of conflict on volunteer turnover intentions}

Work-family conflict and family-work conflict has been related to various negative outcomes, including diminished job and life satisfaction, alcohol use, depression, and poor physical health (Boyar, Maertz Jr, Pearson, \& Keough, 2003). It makes sense to assume that conflict between other domains, such as volunteering and family, also relates to negative outcomes. In particular, when people experience conflict between two domains in life, they will likely withdraw from one domain to eliminate the conflict (Greenhaus, Parasuraman, \& 
Collins, 2001). Moreover, the stress that is caused by the experienced conflict will increase the likelihood to withdraw. Indeed studies have shown that work-family conflict and family-work conflict relate positively to turnover intentions (Boyar et al., 2003). In this study, I propose that positive relationships will also be found between volunteer-family conflict and family-volunteer conflict. Put differently, when volunteers experience conflict between their volunteering and family activities, they are more likely to consider quitting their volunteering activities.

Hypothesis 1: Volunteer-family conflict and family-volunteer conflict are positively related with turnover intentions.

\section{Psychological contract features and volunteer-family conflict}

For nonprofit organizations, a key question is which factors explain the experience of volunteer-family conflict. Put differently, which characteristics of the exchange relationship between volunteers and the nonprofit organization contribute to the emergence of conflict?

For decades, the literature has relied on psychological contracts as a lens to understand exchange relationships (Rousseau, 1989). A psychological contract can be described as an individual's perception of the mutual obligations that exist between him- or herself and another party, such as a nonprofit organization (Rousseau, 1989). These psychological contracts are highly subjective and idiosyncratic. The concept has been applied extensively to understand the exchange relationship of paid employees, and has been shown to explain various employee attitudes and behaviors (Zhao, Wayne, Glibkowski, \& Bravo, 2007). In recent years, the concept is increasingly applied to study non-traditional exchange relationships, such as between volunteers and nonprofit organizations (Nichols, 2013; Vantilborgh \& Van Puyvelde, 2018). Given that volunteers have no formal contract, the psychological contract is considered essential to understand their behavior (Nichols, 2013). 
Psychological contract research typically focuses on either what is being exchanged (content) or on how individuals' react when obligations are (not) fulfilled (process) (Conway \& Briner, 2009). I propose that the characteristics of the exchange relationship are essential to understand volunteer-family conflict, and will therefore focus on content rather than on process. To study content, scholars often differentiate distinct psychological contract types (Rousseau, 1990). Three psychological contract types that are relevant for volunteers are transactional, relational, and ideological contracts (Vantilborgh et al., 2012). Transactional contracts involve tangible inducements and obligations that are exchanged within a well-defined short-term time-frame. Relational contracts focus on the exchange of socio-emotional inducements, that don't have a clear time-frame and stimulate a long-term, trusting relationship between both parties. Ideological contracts, finally, involve value-driven obligations that relate to the mission, cause, and principles of the organization. These psychological contract types have been shown to relate to various outcomes, including volunteer performance (Vantilborgh et al., 2013b). However, psychological contract types also face a number of issues. For example, some inducements or obligations are difficult to categorize consistently into a psychological contract type (Robinson \& Rousseau, 1994). Moreover, the inducements and obligations that pertain to a certain psychological contract type can take various meanings depending on the context of the exchange relationship. An alternative therefore is to use features to describe the content of the psychological contract.

A features-approach describes psychological contracts along certain dimensions (Sels et al., 2004). This idea of dimensions that describe the content of psychological contracts dates back to MacNeil (1980) and was later used by Rousseau (1989) to distinguish transactional from relational psychological contract types. Sels and colleagues (2004) developed and validated six features that can be used to describe exchange relationships: tangibility, scope, stability, time frame, exchange symmetry, and contract level. First, tangibility describes whether a psychological contract contains vague, ambiguous obligations or tangible, explicitly defined obligations. Second, scope ranges from narrow to broad, with narrow 
exchanges signaling a strict division between the exchange relationship and other domains in life and broad indicating that the boundaries between these domains is blurry and permeable. Third, stability refers to the extent to which the psychological contract is stable versus dynamic. In the latter case, the obligations in the contract are flexible and can be negotiated over time. Fourth, time frame signifies whether the exchange is short-term versus long-term and open-ended. Fifth, exchange symmetry refers to the extent to which an individual accepts inequality in the exchange relationship. An unequal exchange symmetry means that the individual accepts hierarchy and formal relationships. Finally, contract level indicates whether individuals perceive their psychological contract as collectively regulated or individually negotiated. In the later case, the contract could be seen to reflect an i-deal or highly individualized and negotiated agreement (Rousseau, Ho, \& Greenberg, 2006).

I propose that several of these psychological contract features relate to the experience of conflict between volunteering and family life. Broadly speaking, some exchange relationships of volunteers are characterized by a number of features that require a high level of commitment and participation on behalf of the volunteer, which increases the likelihood that this commitment to volunteering starts to interfere with other commitments. First, exchange relationships that are characterized by intangible obligations may increase the risk of conflict, because it is less clear to volunteers what will be expected from them (Sels et al., 2004). The ambiguity of the obligations may lead to volunteers being required to perform activities that were not anticipated. In contrast, explicitly communicated and tangible obligations may offer a clear depiction of what the volunteer needs to do, and thus help with maintaining clear boundaries between volunteering and other domains in life (Hustinx, 2010; Hustinx \& Lammertyn, 2003). Second, when the exchange relationship is characterized by a broad scope, the boundary between volunteering and the family domain is blurry and permeable (Sels et al., 2004). This increases the likelihood of conflict between both domains. In contrast, a narrow psychological contract ensures that volunteering is seen as a separate from other domains in life. Third, exchange relationships that are characterized by stability 
increase the predictability of future events (Sels et al., 2004). Volunteers know what is expected from them, and they can be relatively sure that these obligations will not change in the (near) future. In contrast, flexible exchange relationships require that the volunteers adapt to ever-changing circumstances and that their obligations vary considerably over time. As such, flexible psychological contracts may increase the likelihood of conflict, due to their unpredictability. Fourth, exchange relationships with a long time-frame require a high level of commitment and dedication from volunteers (Sels et al., 2004). This level of commitment may lead to conflict, as the volunteer work may start to interfere with family responsibilities. Finally, there are no theoretical reasons to predict a relationship between exchange symmetry and contract level on the one hand and volunteer-family conflict on the other hand. I will therefore explore if any relationships can be found. Based on the above arguments, I propose the following:

Hypothesis 2a: There will be a negative relationship between tangibility (tangible) and volunteer-family or family-volunteer conflict.

Hypothesis 2b: There will be a positive relationship between scope (broad) and volunteer-family or family-volunteer conflict.

Hypothesis 2c: There will be a negative relationship between stability (stable) and volunteer-family or family-volunteer conflict.

Hypothesis 2d: There will be a positive relationship between time-frame (long-term) and volunteer-family or family-volunteer conflict.

Research question 1: Are there relationships between exchange symmetry and contract level on the one hand and volunteer-family or family-volunteer conflict on the other hand.

\section{INSERT FIGURE 1 ABOUT HERE}

The hypotheses above suggest that volunteer-family conflict mediates the effects of 
psychological contract features on turnover intentions. Put differently, I propose that volunteers whose exchange relationship is characterized by intangible, broad, flexible, and long-term obligations will have a higher intention to leave their nonprofit organization, because they experience more conflict between the volunteering and the family-life domains. As such, volunteer-family conflict can help to explain why some exchange relationships increase the likelihood of volunteers quitting their organization. Figure 1 shows the hypothesized mediation model.

Hypothesis 3: Effects of psychological contract features on turnover intentions are mediated by volunteer-family conflict and family-volunteer conflict

\section{Participants and procedure}

\section{Methods}

I recruited participants by contacting Belgian non-profit organizations active in the domains of "human rights, minorities, and third-world support" and "youth and wellbeing". Organizations that agreed to participate, distributed an email containing a link to an online survey among their volunteers. Participation was completely anonymous. In total, 396 volunteers from 29 different non-profit organizations participated in the study. Most participants were female (55.30\%), while the mean age of participants was 46.59 years $(S D=19.39)$. Participants were active in, on average, $2.16(S D=1.85)$ different non-profit organizations (they were asked to report on their activities in the organization for which they volunteered most). On average, participants had $8.51(S D=8.82)$ years of experience volunteering in their present non-profit organization. 


\section{Material}

Turnover intention was assessed with a three-item measure (Mobley, Horner, \& Hollingsworth, 1978). Respondents were asked to answer each item on a seven-point Likert scale. The internal reliability of this scale was relatively low, which may be due to the low amount of items in the scale $(\alpha=0.57)$

To measure volunteer-family conflict, I used an adapted version of the scale by Netemeyer, Boles, and McMurrian (1996). This scale was originally developed to assess work-family conflict. All references to work were changed into volunteering in the adapted version and two extra items were added. Respondents were asked to answer each item on a seven-point Likert scale. The adapted scale contained 30 items, half measuring volunteer-family conflict and the other half measuring family-volunteer conflict. The internal reliability of the volunteer-family conflict $(\alpha=0.93)$ and the family-volunteer conflict $(\alpha=0.93)$ scales were excellent.

To measure psychological contract features, I used the measure by Sels and colleagues (2004). This measure contains 32 items, which respondents rated on a five-point Likert scale. We adapted this measure by changing references to "employer", "employee", or "career" into "volunteer", "non-profit organization", and "volunteering career". The measure contains 17 items that assess features of the organization's obligations, while the remaining 15 items assess features of the volunteer's obligations. For this study, I will focus on the organizational obligations features. The scales measuring organizational features' time-frame ( $\alpha=0.72)$, tangibility $(\alpha=0.84)$, scope $(\alpha=0.68)$, stability $(\alpha=0.63)$, and contract level $(\alpha=0.85)$ attained adequate to good internal reliability scores. 


\section{Data analysis}

To test the hypotheses, I estimated path models in R (R Core Team, 2019). In line with open science recommendations (Banks et al., 2018), the data and all analysis scripts can be downloaded from https://osf.io/4djta/. This manuscript is reproducible and was written and composed using Rmarkdown (Xie, Dervieux, \& Riederer, 2020) and the papaja package (Aust \& Barth, 2018).

\section{Descriptive statistics}

Table 1 shows the means, standard deviations, and correlation coefficients for all variables in the study. Based on these correlations, we can see that the time-frame and scope features are positively related to volunteer-family and family-volunteer conflict. Moreover, both forms of conflict are positively related to intentions to turnover. Visual inspection of the data showed that turnover intentions had a skewed distribution, and thus possibly violated the assumption of normally distributed data for our analyses. We therefore log-transformed this variable.

\section{INSERT TABLE 1 ABOUT HERE}

\section{Multiple regression analysis}

\section{INSERT TABLES 2-4 ABOUT HERE}

Before running path models to test indirect effects, I ran multiple regression models to test Hypotheses 1 and 2 and assess Research Question 1. To test Hypothesis 1, I regressed (log-transformed) turnover intentions on volunteer-family and family-volunteer conflict (see 
Table 2). This model explained $3.82 \%$ of the variance in turnover intentions $(F(2,388)=7.71, p=0.00)$. However, as can be seen in Table 2, neither volunteer-family conflict or family-volunteer conflict significantly explained turnover intentions.

Next, I ran a regression model with volunteer-family conflict as the dependent variable and psychological contract features as the independent variables (see Table 3). This model explained $3.25 \%$ of the variance in volunteer-family conflict $(F(5,390)=2.62, p=0.02)$. Time-frame was positively and significantly related to volunteer-family conflict, offering support to Hypothesis 2d.

Finally, I ran a regression model with family-volunteer conflict as the dependent variable and psychological contract features as the independent variables (see Table 4). This model explained $7.11 \%$ of the variance in family-volunteer conflict $(F(5,385)=5.90, p=0.00)$. Time-frame was positively and significantly related to family-volunteer conflict, again offering support to Hypothesis 2d. Stability was significantly negatively related to family-volunteer conflict, thus supporting Hypothesis 2c.

\section{Path analysis}

\section{INSERT TABLES 5-6 ABOUT HERE}

Next, I estimated a path model, allowing testing of direct and indirect effects. I used a robust maximum likelihood estimator to estimate a partial mediation model. This model was just-identified, meaning that fit indices cannot be used as they are automatically maximized. Table 5 contains the parameter estimates from this model. As can be seen in this table, I find a positive, significant effect of family-volunteer conflict on turnover intentions, offering partial support for Hypothesis 1. Moreover, time-frame was negatively and significantly related to turnover intentions, meaning that volunteers who's psychological contract is characterized by a long time-frame are less inclined to leave the organization. 
However, time-frame was positively and significantly related to volunteer-family and family-volunteer conflict, suggesting that volunteers with a long time frame experience more conflict between both domains. This offers support for Hypothesis 2d. Finally, stability was negatively and significantly related to family-volunteer conflict, meaning that volunteers who perceive that their psychological contract remained stable over time, experienced less interference of their family role and activities into their volunteering activities. This offers some support for Hypothesis 2c. Table 5 only contains direct effects, but it is important to mention that I also included the covariance between volunteer-family and family-volunteer conflict, which indicated that both types of conflict are positively related to each other (Estimate $=0.85, p=0)$

Finally, I used a products-of-coefficients approach to estimate and test indirect effects of PC features on turnover intentions, via volunteer-family and family-volunteer conflict. However, as can be seen in Table 6, none of the indirect effects were significant, meaning that the results do not support Hypothesis 3.

Discussion

The goal of this study was to investigate whether volunteers who's psychological contract was characterized by instability, a broad scope, intangibility, and a long time-frame would be more likely to quit their volunteering activities, because they experience more conflict between their volunteering and family roles and activities. I did not find evidence for this mediating effect of volunteer-family conflict in the relationship between PC features and turnover intentions of volunteers. However, I did find evidence for a weak positive relationship between family-to-volunteer conflict and turnover intentions, meaning that volunteers who perceived that their family role hindered their volunteering activities were more likely to quit. In addition, the results suggested that volunteers who perceived a long time-frame in the relationship with their non-profit organization were more likely to 
experience volunteer-to-family and family-to-volunteer conflict, while volunteers who felt that their psychological contract was stable and did not change regularly over time were less likely to experience family-to-volunteer conflict. Finally, volunteers who perceived a long time-frame in the relationship with their non-profit organization were also less likely to quit volunteering.

This study's findings carry a number of theoretical implications. First, I find some evidence that the content of volunteers' PCs is related to the experience of conflict between the volunteering and the family domain. Essentially, this implies that the mutual obligations that exist between volunteers and nonprofit organizations can potentially increase the risk of conflict. In particular, when these obligations focus on a long-term exchange relationship, volunteers may start to experience more conflict between their volunteering and their family activities (Sels et al., 2004). On the one hand, the level of commitment that is required for a long-term volunteering engagement may require more time and energy from volunteers, impeding their family activities. On the other hand, volunteers who are willing to engage in a long-term exchange relationship may be so committed that they start to perceive family activities as hindering their volunteering tasks. I also found that volunteers with stable PCs are less likely to experience family-to-volunteer conflict. This could be explained by stable contracts being more predictable, making it easier to plan volunteering activities around family responsibilities. It is important, however, to point out that these data do not establish causality of effects. Hence, it is possible that volunteers who are less prone to experience conflict seek out short-term and stable PCs.

Second, the content of volunteers' PCs was also directly related to turnover intentions of volunteers. This finding adds to a body of literature showing that the content of PCs can explain differences in attitudes and behaviors of paid employees (Bal, De Lange, Jansen, \& Van Der Velde, 2008; Zhao et al., 2007) and of volunteers (Nichols, 2013; Vantilborgh, 2015; Vantilborgh, Bidee, Pepermans, Griep, \& Hofmans, 2016). In other words, what volunteers 
perceive as mutual obligations shapes how they feel, think, and behave while volunteering, just as when volunteers perceive that these mutual obligations are (un)fulfilled. In particular, I find that volunteers who had a long time-frame in their exchange relationship were less likely to turnover. This finding does not come as a surprise, as a PC characterized by a long time-frame indicates a willingness to remain a member of a non-profit organization for a longer time period as well. Again, it is important to point out that these results are unable to pinpoint the causal direction of the effect. It is possible that volunteers who have not yet quit, consider their exchange agreement to have a longer time-frame.

Third, the results show that there is a weak relationship between family-to-volunteer conflict and turnover intentions. Because this effect was weak, we could not observe any mediation effects. However, this result tentatively suggests that conflict between the family and the volunteering domain can lead to volunteers deciding to stop their volunteering activities. In particular, when volunteers feel that their family role and responsibilities hinders their volunteering activities, they may decide to quit. This could help them to alleviate the negative emotions that surround the experienced conflict, or they may quit because they believe that they are not really contributing to the non-profit organization due to the experienced conflict. Overall, the findings of this study suggest that the concepts of volunteer-to-family conflict and family-to-volunteer conflict can be relevant to understand volunteers' behaviors. While the results of this study remain limited to weak effects, it is possible that volunteer-family conflict plays an important role in explaining other attitudes and behaviors of volunteers, such as their commitment or the emotions felt while volunteering.

The findings from this study can also be translated into a number of practical implications. For non-profit organizations, it seems advisable to stimulate the development of long-term exchange relationships to reduce turnover of volunteers. This can be achieved by engaging volunteers in long-term or recurring projects, rather than assigning them to 
short-lived activities. However, some authors have pointed out that non-profit organizations increasingly make use of well-defined, short-term projects as many volunteers seek sporadic forms of volunteering (Hustinx \& Lammertyn, 2003; Vantilborgh et al., n.d.). In such cases, it might be worthwhile to frame these short-term projects as smaller parts of a larger, encompassing project, thus offering volunteers a long-term perspective as well. That being said, non-profit organizations also need to be careful with emphasizing long-term exchange agreements, as it may lead to such a high level of engagement that volunteers start to experience conflict with their family responsibilities. Put differently, emphasizing a long-term exchange relationship could be a double-edged sword. To prevent such conflict, non-profit organizations could ensure that mutual obligations are clear and do not change regularly, so that volunteers experience a level of predictability and are able to seek a balance between their volunteering activities and other domains in life.

A number of limitations need to be taken into account when interpreting the findings of this study. First, the sample consisted of volunteers from non-profit organizations in a specific context (human rights, minorities, third-world support and youth and wellbeing). Therefore, the results may not generalize to non-profit organizations active in other domains. Moreover, respondents could choose whether to participate or not, meaning that selection bias may have influenced the results. For example, it is possible that volunteers who experienced high levels of conflict or turnover intentions were less likely to opt into the study. The findings of this study should therefore be replicated in a different sample and context. Second, the reliability of the intentions to turnover scale was rather low, which could be due to the small number of items in the scale. Low reliability may attenuate effects and could potentially explain some of the non-significant results. Using a longer, more reliable measure of turnover intentions in future studies is therefore recommended. Finally, the effect sizes observed in this study were rather small. This suggests that other variables play an important role in explaining volunteer-family conflict and volunteer turnover intentions. 
In general, the findings of this study highlight that volunteer-to-family conflict and family-to-volunteer conflict are potentially important variables to study in a volunteering context. Future studies could extend this research by including conflict between other domains, such as volunteering and work. For example, volunteers who perceive that their volunteering individuals impede their professional activities may decide to quit volunteering, as not to jeopardize their paid employment. In addition, future research could relate volunteer-to-family conflict and family-to-volunteer conflict to other outcomes, such as volunteer motivation, engagement, satisfaction, and commitment. Likewise, alternative antecedents of conflict could be explored, such as personality traits and support from other volunteers. In view of the psychological contract, the concept of psychological contract balance could be related to conflict (Vantilborgh et al., 2013a). Psychological contract balance captures an individual's perception of the balance between volunteer obligations and organizational obligations. A psychological contract that is imbalanced-for example, including many obligations on behalf of the volunteer in exchange for few obligations of the organization-may increase the risk of experiencing conflict, as it signals that volunteering places many demands on volunteers. 


\section{References}

Aust, F., \& Barth, M. (2018). papaja: Create APA manuscripts with R Markdown. Retrieved from https://github.com/crsh/papaja

Bakker, A. B., \& Demerouti, E. (2007). The job demands-Resources model: State of the art. Journal of Managerial Psychology, 22(3), 309-328. Journal Article. doi:10.1108/02683940710733115

Bakker, A. B., Demerouti, E., \& Verbeke, W. (2004). Using the job demands-resources model to predict burnout and performance. Human Resource Management, 43(1), 83-104. Journal Article. doi:10.1002/hrm.20004

Bal, P. M., De Lange, A. H., Jansen, P. G. W., \& Van Der Velde, M. E. G. (2008). Psychological contract breach and job attitudes: A meta-analysis of age as a moderator. Journal of Vocational Behavior, 72(1), 143-158. Journal Article. doi:10.1016/j.jvb.2007.10.005

Banks, G. C., Field, J. G., Oswald, F. L., O’Boyle, E. H., Landis, R. S., Rupp, D. E., \& Rogelberg, S. G. (2018). Answers to 18 questions about open science practices. Journal of Business and Psychology. Journal Article. doi:10.1007/s10869-018-9547-8

Boyar, S. L., Maertz Jr, C. P., Pearson, A. W., \& Keough, S. (2003). Work-family conflict: A model of linkages between work and family domain variables and turnover intentions. Journal of Managerial Issues, 175-190.

Butler, A., Grzywacz, J., Bass, B., \& Linney, K. (2005). Extending the demands-control model: A daily diary study of job characteristics, work-family conflict and work-family facilitation. Journal of Occupational and Organizational 
Psychology, 78(2), 155-169. Journal Article. doi:10.1348/096317905X40097

Conway, N., \& Briner, R. (2009). Fifty years of psychological contract research. What do we know and what are the main challenges? In International review of industrial and organizational psychology (Vol. 24, pp. 71-130). Book Section, John Wiley \& Sons Inc.

Greenhaus, J. H., Parasuraman, S., \& Collins, K. M. (2001). Career involvement and family involvement as moderators of relationships between work-family conflict and withdrawal from a profession. Journal of Occupational Health Psychology, 6(2), 91 .

Hakanen, J. J., Schaufeli, W. B., \& Ahola, K. (2008). The job demands-resources model: A three-year cross-lagged study of burnout, depression, commitment, and work engagement. Work \& Stress, 22(3), 224-241. Journal Article. doi:10.1080/02678370802379432

Hustinx, L. (2010). I quit, therefore i am?: Volunteer turnover and the politics of self-actualization. Nonprofit and Voluntary Sector Quarterly, 39(2), 236-255. Journal Article. doi:10.1177/0899764008328183

Hustinx, L., \& Lammertyn, F. (2003). Collective and reflexive styles of volunteering: A sociological modernization perspective, 21. Journal Article.

Lesener, T., Gusy, B., \& Wolter, C. (2018). The job demands-resources model: A meta-analytic review of longitudinal studies. Work \&6 Stress, 33(1), 76-103. Journal Article. doi:10.1080/02678373.2018.1529065

Macneil, I. R. (1980). The new social contract. New Haven, CT: Yale University Press. 
Miller, L. E., Powell, G. N., \& Seltzer, J. (1990). Determinants of turnover among volunteers. Human Relations, 43(9), 901-917. Journal Article. doi:10.1177/001872679004300906

Mobley, W. H., Horner, S. O., \& Hollingsworth, A. T. (1978). An evaluation of precursors of hospital employee turnover. Journal of Applied Psychology, 63(4), 408.

Netemeyer, R. G., Boles, J. S., \& McMurrian, R. (1996). Development and validation of work-family conflict and family-work conflict scales. Journal of Applied Psychology, $81(4), 400$.

Nichols, G. (2013). The psychological contract of volunteers: A new research agenda. VOLUNTAS: International Journal of Voluntary and Nonprofit Organizations, 24(4), 986-1005. Journal Article. doi:10.1007/s11266-012-9294-9

R Core Team. (2019). R: A language and environment for statistical computing. Vienna, Austria: R Foundation for Statistical Computing. Retrieved from https://www.R-project.org/

Robinson, S. L., \& Rousseau, D. M. (1994). Violating the psychological contract: Not the exception but the norm. Journal of Organizational Behavior, 15(3), 245-259. Journal Article. doi:10.1002/job.4030150306

Rousseau, D. M. (1989). Psychological and implied contracts in organizations. Employee Responsibilities and Rights Journal, 2(2), 121-139. Journal Article. doi:10.1007/BF01384942

Rousseau, D. M. (1990). New hire perceptions of their own and their employer's obligations: A study of psychological contracts. Journal of Organizational Behavior, 11(5), 389-400. Journal Article. doi:10.1002/job.4030110506 
Rousseau, D. M., Ho, V. T., \& Greenberg, J. (2006). I-deals: Idiosyncratic terms in employment relationships. Academy of Management Review, 31(4), 977-994. Journal Article. doi:10.5465/amr.2006.22527470

Sels, L., Janssens, M., \& Van Den Brande, I. (2004). Assessing the nature of psychological contracts: A validation of six dimensions. Journal of Organizational Behavior, 25(4), 461-488. Journal Article. doi:10.1002/job.250

Vantilborgh, T. (2015). Volunteers' reactions to psychological contract fulfillment in terms of exit, voice, loyalty, and neglect behavior. VOLUNTAS: International Journal of Voluntary and Nonprofit Organizations, 26(2), 604-628. Journal Article. doi:10.1007/s11266-014-9441-6

Vantilborgh, T., Bidee, J., Pepermans, R., Griep, Y., \& Hofmans, J. (2016). Antecedents of psychological contract breach: The role of job demands, job resources, and affect. PLOS ONE, 11(5), e0154696. Journal Article. doi:10.1371/journal.pone.0154696

Vantilborgh, T., Bidee, J., Pepermans, R., Willems, J., Huybrechts, G., \& Jegers, M. (2012). Volunteers' psychological contracts: Extending traditional views. Nonprofit and Voluntary Sector Quarterly, 41(6), 1072-1091.

Vantilborgh, T., Bidee, J., Pepermans, R., Willems, J., Huybrechts, G., \& Jegers, M. (2013a). From "getting" to "giving": Exploring age-related differences in perceptions of and reactions to psychological contract balance. European Journal of Work and Organizational Psychology, 22(3), 293-305. Journal Article. doi:10.1080/1359432X.2012.721354

Vantilborgh, T., Bidee, J., Pepermans, R., Willems, J., Huybrechts, G., \& Jegers, M. (2013b). Revisiting the relationship between personality and psychological 
contracts: A moderated mediation model explaining volunteer performance. Social Service Review, 87(1), 158-186. Journal Article. doi:10.1086/669825

Vantilborgh, T., Bidee, J., Pepermans, R., Willems, J., Huybrechts, G., \& Jegers, M. (n.d.). A new deal for npo governance and management: Implications for volunteers using psychological contract theory, 21. Journal Article.

Vantilborgh, T., \& Van Puyvelde, S. (2018). Volunteer reliability in nonprofit organizations: A theoretical model. VOLUNTAS: International Journal of Voluntary and Nonprofit Organizations, 29(1), 29-42. Journal Article. doi:10.1007/s11266-017-9909-2

Willems, J., Huybrechts, G., Jegers, M., Vantilborgh, T., Bidee, J., \& Pepermans, R. (2012). Volunteer decisions (not) to leave: Reasons to quit versus functional motives to stay. Human Relations, 65(7), 883-900. Journal Article. doi:10.1177/0018726712442554

Xie, Y., Dervieux, C., \& Riederer, E. (2020). $R$ markdown cookbook. Boca Raton, Florida: Chapman; Hall/CRC. Retrieved from https://bookdown.org/yihui/rmarkdown-cookbook

Zhao, H., Wayne, S. J., Glibkowski, B. C., \& Bravo, J. (2007). The impact of psychological contract breach on work-related outcomes: A meta-analysis. Personnel Psychology, 60(3), 647-680. Journal Article. doi:10.1111/j.1744-6570.2007.00087.x

Aust, F., \& Barth, M. (2018). papaja: Create APA manuscripts with $R$ Markdown. Retrieved from https://github.com/crsh/papaja

Bakker, A. B., \& Demerouti, E. (2007). The job demands-Resources model: State of the art. Journal of Managerial Psychology, 22(3), 309-328. Journal Article. 
doi:10.1108/02683940710733115

Bakker, A. B., Demerouti, E., \& Verbeke, W. (2004). Using the job demands-resources model to predict burnout and performance. Human Resource Management, 43(1), 83-104. Journal Article. doi:10.1002/hrm.20004

Bal, P. M., De Lange, A. H., Jansen, P. G. W., \& Van Der Velde, M. E. G. (2008). Psychological contract breach and job attitudes: A meta-analysis of age as a moderator. Journal of Vocational Behavior, 72(1), 143-158. Journal Article. doi:10.1016/j.jvb.2007.10.005

Banks, G. C., Field, J. G., Oswald, F. L., O’Boyle, E. H., Landis, R. S., Rupp, D. E., \& Rogelberg, S. G. (2018). Answers to 18 questions about open science practices. Journal of Business and Psychology. Journal Article. doi:10.1007/s10869-018-9547-8

Boyar, S. L., Maertz Jr, C. P., Pearson, A. W., \& Keough, S. (2003). Work-family conflict: A model of linkages between work and family domain variables and turnover intentions. Journal of Managerial Issues, 175-190.

Butler, A., Grzywacz, J., Bass, B., \& Linney, K. (2005). Extending the demands-control model: A daily diary study of job characteristics, work-family conflict and work-family facilitation. Journal of Occupational and Organizational Psychology, 78(2), 155-169. Journal Article. doi:10.1348/096317905X40097

Conway, N., \& Briner, R. (2009). Fifty years of psychological contract research. What do we know and what are the main challenges? In International review of industrial and organizational psychology (Vol. 24, pp. 71-130). Book Section, John Wiley \& Sons Inc.

Greenhaus, J. H., Parasuraman, S., \& Collins, K. M. (2001). Career involvement and 
family involvement as moderators of relationships between work-family conflict and withdrawal from a profession. Journal of Occupational Health Psychology, 6(2), 91 .

Hakanen, J. J., Schaufeli, W. B., \& Ahola, K. (2008). The job demands-resources model: A three-year cross-lagged study of burnout, depression, commitment, and work engagement. Work \& Stress, 22(3), 224-241. Journal Article. doi:10.1080/02678370802379432

Hustinx, L. (2010). I quit, therefore i am?: Volunteer turnover and the politics of self-actualization. Nonprofit and Voluntary Sector Quarterly, 39(2), 236-255. Journal Article. doi:10.1177/0899764008328183

Hustinx, L., \& Lammertyn, F. (2003). Collective and reflexive styles of volunteering: A sociological modernization perspective, 21. Journal Article.

Lesener, T., Gusy, B., \& Wolter, C. (2018). The job demands-resources model: A meta-analytic review of longitudinal studies. Work \&6 Stress, 33(1), 76-103. Journal Article. doi:10.1080/02678373.2018.1529065

Macneil, I. R. (1980). The new social contract. New Haven, CT: Yale University Press.

Miller, L. E., Powell, G. N., \& Seltzer, J. (1990). Determinants of turnover among volunteers. Human Relations, 43(9), 901-917. Journal Article. doi:10.1177/001872679004300906

Mobley, W. H., Horner, S. O., \& Hollingsworth, A. T. (1978). An evaluation of precursors of hospital employee turnover. Journal of Applied Psychology, 63(4), 408. 
Netemeyer, R. G., Boles, J. S., \& McMurrian, R. (1996). Development and validation of work-family conflict and family-work conflict scales. Journal of Applied Psychology, 81(4), 400.

Nichols, G. (2013). The psychological contract of volunteers: A new research agenda. VOLUNTAS: International Journal of Voluntary and Nonprofit Organizations, 24(4), 986-1005. Journal Article. doi:10.1007/s11266-012-9294-9

R Core Team. (2019). R: A language and environment for statistical computing. Vienna, Austria: R Foundation for Statistical Computing. Retrieved from https://www.R-project.org/

Robinson, S. L., \& Rousseau, D. M. (1994). Violating the psychological contract: Not the exception but the norm. Journal of Organizational Behavior, 15(3), 245-259. Journal Article. doi:10.1002/job.4030150306

Rousseau, D. M. (1989). Psychological and implied contracts in organizations. Employee Responsibilities and Rights Journal, 2(2), 121-139. Journal Article. doi:10.1007/BF01384942

Rousseau, D. M. (1990). New hire perceptions of their own and their employer's obligations: A study of psychological contracts. Journal of Organizational Behavior, 11(5), 389-400. Journal Article. doi:10.1002/job.4030110506

Rousseau, D. M., Ho, V. T., \& Greenberg, J. (2006). I-deals: Idiosyncratic terms in employment relationships. Academy of Management Review, 31(4), 977-994. Journal Article. doi:10.5465/amr.2006.22527470

Sels, L., Janssens, M., \& Van Den Brande, I. (2004). Assessing the nature of psychological contracts: A validation of six dimensions. Journal of Organizational Behavior, 25(4), 461-488. Journal Article. doi:10.1002/job.250 
Vantilborgh, T. (2015). Volunteers' reactions to psychological contract fulfillment in terms of exit, voice, loyalty, and neglect behavior. VOLUNTAS: International Journal of Voluntary and Nonprofit Organizations, 26 (2), 604-628. Journal Article. doi:10.1007/s11266-014-9441-6

Vantilborgh, T., Bidee, J., Pepermans, R., Griep, Y., \& Hofmans, J. (2016). Antecedents of psychological contract breach: The role of job demands, job resources, and affect. PLOS ONE, $11(5)$, e0154696. Journal Article. doi:10.1371/journal.pone.0154696

Vantilborgh, T., Bidee, J., Pepermans, R., Willems, J., Huybrechts, G., \& Jegers, M. (2012). Volunteers' psychological contracts: Extending traditional views. Nonprofit and Voluntary Sector Quarterly, 41(6), 1072-1091.

Vantilborgh, T., Bidee, J., Pepermans, R., Willems, J., Huybrechts, G., \& Jegers, M. (2013a). From "getting" to "giving": Exploring age-related differences in perceptions of and reactions to psychological contract balance. European Journal of Work and Organizational Psychology, 22(3), 293-305. Journal Article. doi:10.1080/1359432X.2012.721354

Vantilborgh, T., Bidee, J., Pepermans, R., Willems, J., Huybrechts, G., \& Jegers, M. (2013b). Revisiting the relationship between personality and psychological contracts: A moderated mediation model explaining volunteer performance. Social Service Review, 87(1), 158-186. Journal Article. doi:10.1086/669825

Vantilborgh, T., Bidee, J., Pepermans, R., Willems, J., Huybrechts, G., \& Jegers, M. (n.d.). A new deal for npo governance and management: Implications for volunteers using psychological contract theory, 21. Journal Article.

Vantilborgh, T., \& Van Puyvelde, S. (2018). Volunteer reliability in nonprofit 
organizations: A theoretical model. VOLUNTAS: International Journal of Voluntary and Nonprofit Organizations, 29(1), 29-42. Journal Article. doi:10.1007/s11266-017-9909-2

Willems, J., Huybrechts, G., Jegers, M., Vantilborgh, T., Bidee, J., \& Pepermans, R. (2012). Volunteer decisions (not) to leave: Reasons to quit versus functional motives to stay. Human Relations, 65(7), 883-900. Journal Article. doi:10.1177/0018726712442554

Xie, Y., Dervieux, C., \& Riederer, E. (2020). R markdown cookbook. Boca Raton, Florida: Chapman; Hall/CRC. Retrieved from https://bookdown.org/yihui/rmarkdown-cookbook

Zhao, H., Wayne, S. J., Glibkowski, B. C., \& Bravo, J. (2007). The impact of psychological contract breach on work-related outcomes: A meta-analysis. Personnel Psychology, 60(3), 647-680. Journal Article. doi:10.1111/j.1744-6570.2007.00087.x 
Table 1

Means, standard deviations, and correlations with confidence intervals

\begin{tabular}{|c|c|c|c|c|c|c|c|c|c|}
\hline Variable & M & $\mathrm{SD}$ & 1 & 2 & 3 & 4 & 5 & 6 & 7 \\
\hline 1. otf & 2.61 & 0.87 & & & & & & & \\
\hline 2. ota & 3.68 & 0.90 & $\begin{array}{l}.39^{* *} \\
{[.30, .47]}\end{array}$ & & & & & & \\
\hline 3. osc & 4.22 & 0.68 & $\begin{array}{l}.41^{* *} \\
{[.33, .49]}\end{array}$ & $\begin{array}{l}.49^{* *} \\
{[.41, .56]}\end{array}$ & & & & & \\
\hline 4. ost & 3.52 & 0.73 & $\begin{array}{l}.18^{* *} \\
{[.09, .28]}\end{array}$ & $\begin{array}{l}.37^{* *} \\
{[.28, .45]}\end{array}$ & $\begin{array}{l}.43^{* *} \\
{[.34, .50]}\end{array}$ & & & & \\
\hline 5. ocl & 3.91 & 0.82 & $\begin{array}{l}.21^{* *} \\
{[.12, .30]}\end{array}$ & $\begin{array}{l}.38^{* *} \\
{[.29, .46]}\end{array}$ & $\begin{array}{l}.45^{* *} \\
{[.36, .52]}\end{array}$ & $\begin{array}{l}.48^{* *} \\
{[.40, .55]}\end{array}$ & & & \\
\hline 6. vfc & 2.61 & 1.11 & $\begin{array}{l}.17^{* *} \\
{[.07, .27]}\end{array}$ & $\begin{array}{l}.07 \\
{[-.03, .17]}\end{array}$ & $\begin{array}{l}.11^{*} \\
{[.01, .21]}\end{array}$ & $\begin{array}{l}.07 \\
{[-.03, .16]}\end{array}$ & $\begin{array}{l}.08 \\
{[-.02, .17]}\end{array}$ & & \\
\hline 7. fvc & 2.60 & 1.15 & $\begin{array}{l}.24^{* *} \\
{[.14, .33]}\end{array}$ & $\begin{array}{l}.06 \\
{[-.04, .15]}\end{array}$ & $\begin{array}{l}.12^{*} \\
{[.02, .22]}\end{array}$ & $\begin{array}{l}-.05 \\
{[-.15, .05]}\end{array}$ & $\begin{array}{l}.04 \\
{[-.06, .13]}\end{array}$ & $\begin{array}{l}.71^{* *} \\
{[.66, .76]}\end{array}$ & \\
\hline 8. itt & 2.04 & 1.10 & $\begin{array}{l}-.03 \\
{[-.13, .06]}\end{array}$ & $\begin{array}{l}.01 \\
{[-.09, .11]}\end{array}$ & $\begin{array}{l}.04 \\
{[-.05, .14]}\end{array}$ & $\begin{array}{l}.03 \\
{[-.07, .12]}\end{array}$ & $\begin{array}{l}.08 \\
{[-.02, .18]}\end{array}$ & $\begin{array}{l}.19^{* *} \\
{[.10, .29]}\end{array}$ & $\begin{array}{l}.17^{* *} \\
{[.08, .27]}\end{array}$ \\
\hline
\end{tabular}

Note. Note. M and SD are used to represent mean and standard deviation, respectively. Values in square brackets indicate the $95 \%$ confidence interval. * indicates $\mathrm{p}<.05 . * *$ indicates $\mathrm{p}<.01$. Variables: otf $=$ Time-frame, ota $=$ Tangibility, osc $=$ Scope, ost $=$ Stability, ocl $=$ Contract level, vfc $=$ Volunteer-family conflict, fvc $=$ Family-volunteer conflict, itt $=$ Intention to turnover 
Table 2

Results from regression analysis of turnover

intentions on volunteer-family conflict

\begin{tabular}{lcccc}
\hline Predictor & $b$ & $95 \%$ CI & $t(388)$ & $p$ \\
\hline Intercept & 0.34 & {$[0.21,0.47]$} & 5.14 & $<.001$ \\
Vfc & 0.04 & {$[-0.02,0.10]$} & 1.25 & .211 \\
Fvc & 0.05 & {$[-0.01,0.11]$} & 1.73 & .084 \\
\hline
\end{tabular}

Note. $\mathrm{VFC}=$ Volunteer-family conflict, $\mathrm{FVC}=$

Family-volunteer conflict 
Table 3

Results from regression analysis of volunteer-family conflict on psychological contract features

\begin{tabular}{lcccc}
\hline Predictor & $b$ & $95 \%$ CI & $t(390)$ & $p$ \\
\hline Intercept & 1.69 & {$[0.94,2.44]$} & 4.42 & $<.001$ \\
Otf & 0.20 & {$[0.06,0.34]$} & 2.74 & .006 \\
Ota & -0.03 & {$[-0.17,0.12]$} & -0.37 & .711 \\
Osc & 0.07 & {$[-0.14,0.28]$} & 0.66 & .511 \\
Ost & 0.02 & {$[-0.16,0.20]$} & 0.24 & .810 \\
Ocl & 0.04 & {$[-0.12,0.20]$} & 0.44 & .659 \\
\hline
\end{tabular}

Note. OTF $=$ Time-frame, OTA $=$ Tangibility, OSC

$=$ Scope, OST $=$ Stability, OCL $=$ Contract level 
Table 4

Results from regression analysis of family-volunteer conflict on psychological contract features

\begin{tabular}{lcccc}
\hline Predictor & $b$ & $95 \%$ CI & $t(385)$ & $p$ \\
\hline Intercept & 1.92 & {$[1.15,2.70]$} & 4.90 & $<.001$ \\
Otf & 0.31 & {$[0.16,0.45]$} & 4.15 & $<.001$ \\
Ota & -0.05 & {$[-0.20,0.10]$} & -0.65 & .519 \\
Osc & 0.15 & {$[-0.06,0.37]$} & 1.40 & .164 \\
Ost & -0.20 & {$[-0.39,-0.02]$} & -2.17 & .030 \\
Ocl & 0.03 & {$[-0.13,0.20]$} & 0.40 & .690 \\
\hline
\end{tabular}

Note. $\mathrm{OTF}=$ Time-frame, OTA $=$ Tangibility, OSC

$=$ Scope, OST $=$ Stability, OCL $=$ Contract level 
Table 5

Parameter estimates from path analysis

\begin{tabular}{|c|c|c|c|c|c|c|}
\hline To & From & Estimate & se & pvalue & $\mathrm{LB}$ & UB \\
\hline Turnover & Volunteer-family conflict & 0.04 & 0.03 & 0.27 & -0.03 & 0.10 \\
\hline Turnover & Family-volunteer conflict & 0.06 & 0.03 & 0.05 & 0.00 & 0.12 \\
\hline Turnover & Time-frame & -0.07 & 0.03 & 0.04 & -0.13 & 0.00 \\
\hline Turnover & Tangibility & 0.00 & 0.03 & 0.98 & -0.06 & 0.06 \\
\hline Turnover & Scope & 0.04 & 0.05 & 0.38 & -0.05 & 0.14 \\
\hline Turnover & Contract level & 0.04 & 0.04 & 0.23 & -0.03 & 0.11 \\
\hline Turnover & Stability & -0.01 & 0.04 & 0.73 & -0.10 & 0.07 \\
\hline Volunteer-family conflict & Time-frame & 0.18 & 0.08 & 0.02 & 0.03 & 0.33 \\
\hline Volunteer-family conflict & Tangibility & -0.01 & 0.07 & 0.83 & -0.15 & 0.12 \\
\hline Volunteer-family conflict & Scope & 0.10 & 0.11 & 0.32 & -0.10 & 0.31 \\
\hline Volunteer-family conflict & Contract level & 0.04 & 0.08 & 0.59 & -0.12 & 0.20 \\
\hline Volunteer-family conflict & Stability & -0.01 & 0.09 & 0.89 & -0.18 & 0.16 \\
\hline Family-volunteer conflict & Time-frame & 0.31 & 0.07 & 0.00 & 0.17 & 0.45 \\
\hline Family-volunteer conflict & Tangibility & -0.05 & 0.07 & 0.51 & -0.20 & 0.10 \\
\hline Family-volunteer conflict & Scope & 0.15 & 0.12 & 0.19 & -0.07 & 0.38 \\
\hline Family-volunteer conflict & Contract level & 0.03 & 0.08 & 0.67 & -0.12 & 0.19 \\
\hline Family-volunteer conflict & Stability & -0.20 & 0.09 & 0.02 & -0.38 & -0.03 \\
\hline
\end{tabular}


Table 6

Parameter estimates for indirect effects from path analysis

\begin{tabular}{lcccccc}
\hline Independent & Mediator & Estimate & se & pvalue & LB & UB \\
\hline Time-frame & Volunteer-family conflict & 0.01 & 0.01 & 0.30 & -0.01 & 0.02 \\
Tangibility & Volunteer-family conflict & 0.00 & 0.00 & 0.83 & -0.01 & 0.00 \\
Scope & Volunteer-family conflict & 0.00 & 0.01 & 0.49 & -0.01 & 0.01 \\
Contract level & Volunteer-family conflict & 0.00 & 0.00 & 0.63 & 0.00 & 0.01 \\
Stability & Volunteer-family conflict & 0.00 & 0.00 & 0.89 & -0.01 & 0.01 \\
Time-frame & Family-volunteer conflict & 0.02 & 0.01 & 0.08 & 0.00 & 0.04 \\
Tangibility & Family-volunteer conflict & 0.00 & 0.00 & 0.53 & -0.01 & 0.01 \\
Scope & Family-volunteer conflict & 0.01 & 0.01 & 0.27 & -0.01 & 0.03 \\
Contract level & Family-volunteer conflict & 0.00 & 0.00 & 0.67 & -0.01 & 0.01 \\
\cline { 3 - 5 } Stability & Family-volunteer conflict & -0.01 & 0.01 & 0.11 & -0.03 & 0.00 \\
\hline
\end{tabular}




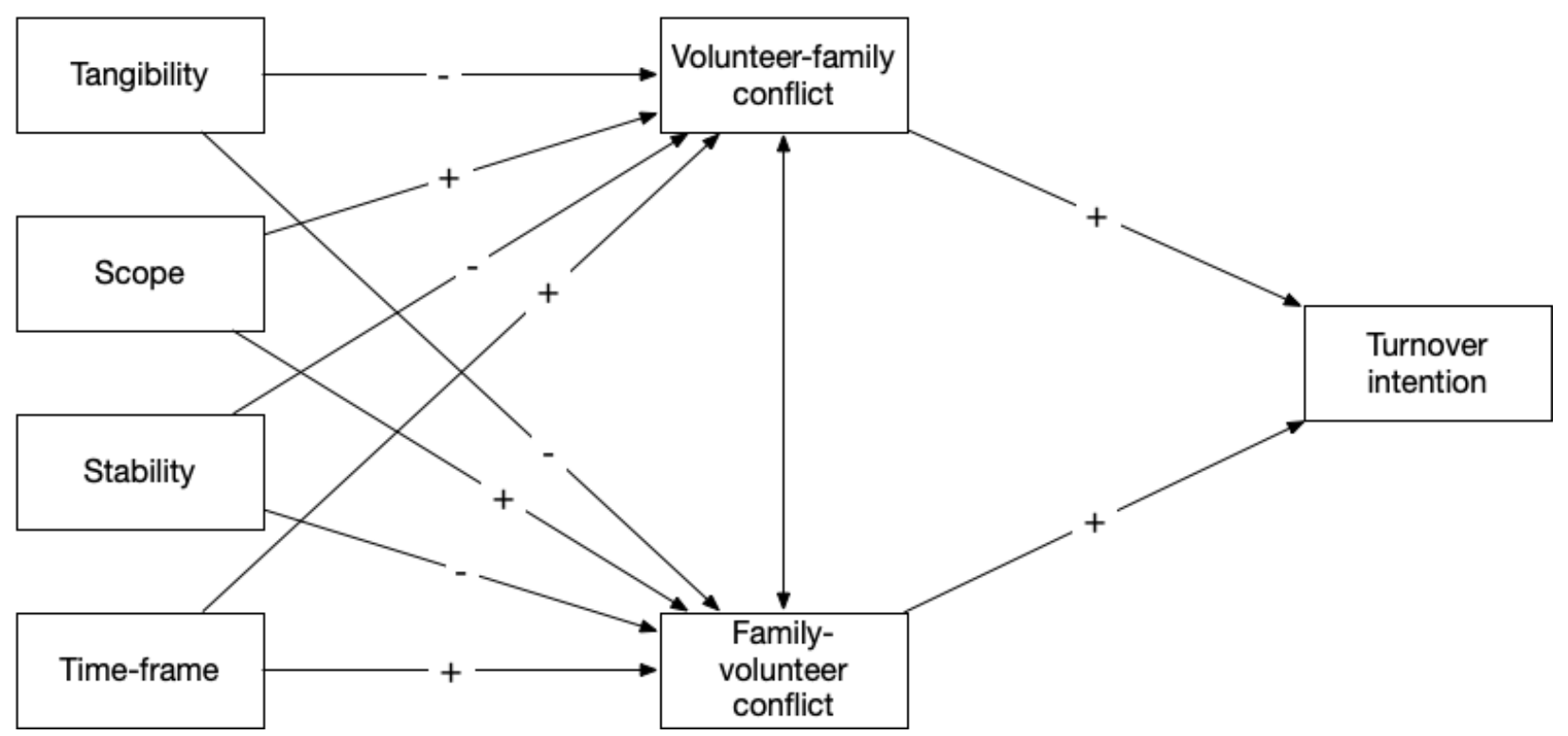

Figure 1. Overview of mediation model 